Толочко Світлана Вікторівна доктор педагогічних наук, доцент, головний науковий співробітник лабораторії позашкільної освіти Інституту проблем виховання, Національна академія педагогічних наук України, вул. М. Берлинського, 9, м. Київ, 04060, тел.: (044) 455-53-38, e-mail: svitlanatsv@ukr.net, tolochkosvitlana331@gmail.com, https://orcid.org/0000-0002-9262-2311

\title{
КЛАСИФІКАЦІЙНІ ОЗНАКИ ПЕДАГОГІЧНОГО КОУЧИНГУ ТА ЙОГО РОЛЬ У ПРОФЕСІЙНОМУ РОЗВИТКОВІ ОСОБИСТОСТІ
}

Анотація. У статті проаналізовано та виокремлено основні підходи до формулювання, визначення й розвитку науково-методичної компетентності за класифікаційними ознаками професіограм викладачів у післядипломній педагогічній освіті, зокрема коучів, концептуалізовано принципи, підходи і технології їхньої підготовки зі сформованою компетентністю синергізму становлення і розвитку. Визначено понятійно-категоріальний апарат дослідження «коуч», «клієнт», «коучинг», «освітній коучинг», «формат коучингу», «коучингова взаємодія», «коучингова сесія», «коучинговий процес». Сформульовано дефініцію поняття «професійна науково-методична компетентність коуча», яка нами розглядається як інтегральна характеристика, інтегральну характеристику, що включає креативну взаємну діяльність незалежних учасників освітнього (освітньо-наукового) процесу, яка здійснюється у формі діалогу, для віднаходження й реалізації можливостей здобувачів освіти та забезпечення власного освітнього, професійного, соціального й особистісного розвитку; є сукупністю розвинених компетентностей (професійно-коучингової, морально-етичної, комунікативної, проєктної, управлінсько-відповідальнісної, інформативно-комунікаційної, мотиваційно-розвиваючої); професійну сформованість розуміння коучингу, його відмінності від консультування, психотерапії та інших методів фахової підтримки клієнтів та ефективне його застосування; відповідальність педагога за використання ефективної спонукально-стимулюючої комунікації; визначення автентичної культурідентифікації потенціалу особистісних переваг здобувачів освіти і основних сфер для навчання й зростання, вирішення важливих питань та розвиток (отримання зворотного зв'язку, установлення переваг і швидкості навчання, рефлексія та навчання на досвіді); відповідність запитам щодо розкриття професійного потенціалу особи для максимального підвищення ефективності. Розроблено професіограму коуча в післядипломній педагогічній освіті 3 характеристикою особливостей професійної підготовки, концептуалізацією системних якостей, знань, умінь, здатностей, сформованості, готовності, відповідальності і відповідності. Актуалізовано науково-методичні інструменти для через визначення принципів, підходів, видів коучингу в освіті, 
технік та провідних ролей. Проаналізовано й виокремлено види компетентностей, очікувані результати та можливості реалізації коучингу в освіті.

Ключові слова: коуч, освіта, науково-методична компетентність, післядипломна педагогічна освіта

Tolochko Svitlana Viktorivna Doctor of Pedagogical Sciences, Associate Professor, chief researcher of the laboratory of extracurricular education Institute of Problems on Education of the NAES of Ukraine, M. Berlinsky St., 9, Kyiv, 04060, tel.: (044) 455-53-38, e-mail: svitlana-tsv@ukr.net, tolochkosvitlana331@gmail.com, https://orcid.org/0000-0002-9262-2311

\title{
CLASSIFICATION FEATURES OF PEDAGOGICAL COACHING AND ITS ROLE IN PROFESSIONAL DEVELOPMENTAL OF THE PERSONALITY
}

\begin{abstract}
The article analyzes and highlights the main approaches to the formulation, definition and development of scientific and method competence according to the classification features of professiograms of teachers in postgraduate pedagogical education, especially coaches, conceptualizes principles, approaches and technologies of their training with the formed competence of synergism of formation and development. The conceptual and categorical apparatus of research "coach", "client", "coaching", "educational coaching", "coaching format", "coaching interaction", "coaching session", "coaching process" is determined. The definition of the term "professional scientific and methodological competence of the coach" is formulated, which we consider as an integral characteristic, an integral characteristic that includes creative interaction of independent participants in the educational (educational-scientific) process, which is carried out in the form of a dialogue and ensures their own educational, professional, social and personal development; is a set of developed competencies (professional-coaching, moral-ethical, communicative, project, managerial-responsible, informative-communicative, motivational-developing); professional development of understanding of coaching, its differences from counseling, psychotherapy and other methods of professional support of clients and its effective application; teacher's responsibility for the use of effective motivational communication; identification of authentic cultural identification of the potential of students' personal preferences and main areas for learning and growth, solution of important issues and development (receiving feedback, establishing benefits and speed of learning, reflection and learning by doing); compliance with the requirements for the disclosure of a person's professional potential to maximize efficiency. The professional profile of a coach in postgraduate pedagogical education with the characteristic of features of professional training, conceptualization of system qualities, knowledge, abilities, formation, readiness, responsibility and conformity is developed. Scientific and methodological tools for defining principles, approaches, types of coaching in education, techniques and leading roles are updated. Types of competencies, expected results and opportunities for coaching in education are analyzed and singled out.
\end{abstract}


Keywords: coach, education, scientific and method competence, postgraduate pedagogical education.

Постановка проблеми. У сучасному суспільстві коучинг застосовують для розвитку творчого потенціалу, лідерських якостей, професійної компетентності особистості. В українській освіті означена технологія мало відома, а тому вивчення, застосування й розвиток цього напряму $є$ надзвичайно актуальним, зважаючи на мету освіти щодо формування нової генерації громадян.

Загальновідомо, що основним компонентом професіоналізму викладача $\epsilon$ прагнення до навчання та постійне вдосконалення. Педагогам, освітнім менеджерам та навіть закладам освіти потрібно безперервно рухатися вперед, кидати виклик та досягати найвищих результатів. У означеному контексті коучинг може стати тією рушійною силою, яка значно підвищить або підтримуватиме високий рівень продуктивності для використання нових можливостей професійного зростання. Коучинг збагатить усіх учасників освітнього процесу.

Аналіз останніх досліджень і публікацій. Провідні дослідження в галузі коучингу здійснювали закордонні науковці Т. Голві, С. Р. Кові, М. Аткінсон, М. Дауні, С. Дуглас, П. Зеус, С. Беттлі, Дж. О’Коннор, У. Морлей, Д. Уітмор тощо, які згодом реалізувалися в бізнесі і в галузі неформальної освіти.

М. Каку, К. Робінсон та інші експерти світового рівня, аналізуючи теперішне й майбутнє освітніх процесів, акцентують на необхідності переходу від передачі знань і навичок до розвитку творчих талантів та інноваційного мислення на всіх ланках - у дошкільних і позашкільних закладах, школі, ЗВО та в контексті подальшої неперервної освіти. На практиці це означає перехід від усталених традицій педагогіки до новітніх парадигм, зокрема й коучингу як максимального розкриття потенціалу людини на усіх вікових етапах іiі розвитку.

Питання коучингу в освіті досліджували українські науковці, зокрема Т. Борова [1], О. Варецька [2], О. Гаврилюк [3], О. Колесниченко [4], I. Петровська [5], Г. Поберезська [6], С. Романова [7], В. Сидоренко [8], I. Чернова [14] тощо.

На основі вивчення теоретичних основ коучингу як сучасної технології професійного розвитку (саморозвитку) працівника досліджено, що коучингова технологія є м'якою у «суб'єкт - об'єктних» зв'язках між керівником і працівником, педагогом і здобувачем освіти й ефективніше спрямовує діяльність людини в особистісному та професійному розвиткові.

Мета статті - структурно-системний аналіз визначення змісту, форм i методів формування науково-методичної компетентності за класифікаційними ознаками професіограм викладачів у післядипломній педагогічній освіті, зокрема коучів, концептуалізація принципів, підходів і технологій їхньої підготовки зі сформованою компетентністю синергізму становлення і розвитку.

Виклад основного матеріалу. Для реалізації мети розкриємо понятійнокатегоріальний апарат дослідження.

Коуч (coach) - фахівець, який проводить коучинг. 
Клієнт - людина або установа, що формує замовлення на надання послуг із тренування рис, якостей, навичок чи компетенцій.

Коучинг - це персональне тренування педагогічних працівників (ПП) чи науково-педагогічних працівників (НПП) задля досягнення ним професійної цілі, задач, зростання результативності планування за IOT на всіх стадіях міжкурсового періоду, використання внутрішнього ресурсу, розвитку потрібних фахових здібностей, здатностей, навичок i компетенцій, опанування прогресивних стратегій, парадигм, технологій.

Коучинг (за визначенням Міжнародної Федерації Коучингу ICF) - це система використання сукупного суспільного, особистісного, креативного ресурсу учасників процесу постійного розвитку педагогічної компетентності 3 метою одержання максимально якісного результату.

Коучинг (за визначенням Міжнародної Федерації Коучингу ICF) - це повсякчасна кооперація для надання допомоги клієнтам у досягненні ними конкретних результатів в особистому та професійному житті 3 метою поглиблення знань, підвищення ККД і покращення якості життя

Формат коучингу - це спосіб спільної діяльності клієнта й тренера у процесі здійснення коучинг-сесії.

Коучингова взасмодія - це належно структурована розмова, у процесі якої використовується активне слухання, бездоганна постановка запитань, компетенції, пов'язані з практичним досвідом та рівнем емоційного інтелекту для зростання обізнаності клієнта та спонукання до відповідальності.

Коучинговий процес включає 3'ясування цілей, досліджування дійсності, аналіз можливих варіантів його результатів, погоджування алгоритму дій та їх виконання, а також перегляду й аналізу дієвості.

Коучинг-сесія - це систематична і структурована форма взаємної діяльності коуча з ПП, НПП, педагогічним колективом, організацією для просування спільно $з$ клієнтом до досягнення поставленої мети і завдань. Зазвичай коучингсесія триває від 30 до 90 хвилин. Коуч, використовуючи технологію «стріли коучингу» (сукупності запитань), спільно 3 клієнтом виявляє властиву йому «карту світу»; запитаннями сприяє ПП, НПП з'ясувати ймовірні соціокультурн й освітні ризики, підшуковує та надає потрібні джерела інформації.

На основі компетентнісного досвіду (життєвого, особистісного, професійного) ПП чи НПП спільно вибирається мета, вибудовується індивідуальна освітня траєкторія розвитку педагогічної майстерності, вивчаються можливі акмеологічні чинники (зовнішні і внутрішні), оцінюються наявні потенційні ресурси. Після допомоги коуча в отриманні необхідної інформації та придбанні відповідних навичок його клієнт вирішує поставлене завдання самостійно. При груповій роботі професійна роль коуча полягає в умінні допомогти учасникам своєї команди досягти певного рівня корпоративної культури, працювати більш ефективно, злагоджено.

Мета коучингу - виявлення можливостей і прихованих резервів особистості для найбільшого підняття власної продуктивності й результативності в роботі. 


\section{Концепція й парадигма освітнього коучингу}

Завдяки високій ефективності коучинг як спеціальна послуга та освітня технологія все частіше зі сфер спорту, психології, бізнесу переходить і в освіту. На думку дослідників, коучинг передусім асоціюється з неформальною освітою (курси підвищення кваліфікації, професійна перепідготовка, навчання на підприємствах) [17; 24; 25]. «Однак останнім часом усе більше публікацій присвячено впровадженню коуч-технік у системі середньої освіти, післядипломній педагогічній освіті: керівники-педагоги діляться власним досвідом щодо проведення коуч-сесій, методичними розробками уроківпрезентацій із використанням елементів коучингу» [19, с. 102].

Освітній коучинг застосовують для формування вмінь, здатностей, компетенцій щодо фахового розвитку викладачів ЗВО.

Стосовно коучингу в освіті маємо кілька визначень:

- Освітній коучинг - взаємини між викладачем і студентами, коли педагог ефективно організовує процес пошуку здобувачами освіти кращих відповідей на запитання, що їх цікавлять.

- Освітній коучинг - система психолого-педагогічних процесів для розвитку й підтримки наявних знань, умінь і компетенцій, що відбуваються у формі діалогу між учасниками освітньої діяльності та охоплюють продуктивний i результативно планомірний зміст [2].

- Освітній коучинг - креативна взаємна діяльність незалежних учасників освітнього процесу, яка здійснюється з метою віднаходження та втілення в життя можливестей здобувачів освіти задля забезпечення ним власного високого освітнього, професійного, соціального та особистісного розвитку

Стрижнева концепція коучингу: під час формування особистості не можна застосовувати насилля, якими благими цілями воно не обгрунтовувалося б. Благо людини - вище за все.

\section{НАУКОВО-МЕТОДИЧНІ ІНСТРУМЕНТИ ДЛЯ КОУЧИНГУ}

Принципи, технології, форми, основні складові моделі розвитку освітнього коучингу

Коучинг активно використовує технології інтерактивного навчання й навчання через зворотний зв'язок. Звичайне навчання не відбиває кореляцію між успіхом у школі або університеті та житті, коучинг стає найбільш важливим шляхом для трансформацій абстрактних знань у реальні компетентності, що практично втілюються в діяльність. Дослідниця Т. Борова, детально проаналізувавши особливості коучингу, стверджує, що освітній коучинг зорієнтований на майбутнє, сфокусований на вирішення питань, спрямований на дію та досвід як основу та має в основі навчання через дію. Одним із підходів у навчанні є діяльнісний, тому освітній коучинг можна вважати технологією, що спрямована на досягнення мети через дію та власний досвід.

Принципи, якими керується коуч у процесі міжособистісної взаємодії:

1. Принщип усвідомлення ци відповідальності. Розуміння всього, що відбувається всередині людини й зовні, його переживання, виважено переконана діяльність, що $є$ результатом узгодженості внутрішнього i зовнішнього, 
особистого і колективного. Усвідомлення передбачає відповідальність коуча за клієнта, результати спільної діяльності із розкриття його можливостей для вирішення поставлених завдань 3 метою найповнішої самореалізації внутрішніх ресурсів. Допомогти студентові виявити, зрозуміти та сформулювати важливі життєві цілі, віднаходити шляхи їх реалізації, сприяти його саморозвиткові; виховувати відповідальність за результат і вибір способів його досягнення.

2. Принциип єдності $i$ взаємодіi передбачає правильне співвідношення методів індивідуального коучингового впливу та суспільної поведінки, усвідомлення взаємозалежності позитивних результатів в одній сфері i досягнень в інших. Розуміння особистісних проблем у взаєминах допомагає унормувати інші види діяльності (алгоритм дій для досягнення цілі з метою високої результативності освітньої і фахової діяльності).

3. Принциип гнучкості. Формування гнучкості, пластичності мислення, розуміння шаблонів власної поведінки. Спільно 3 коучем студенти створюють алгоритм поступового продукування й реалізації власної нової стратегії особистісного й професійного зростання. Це сприяє впевненості в їхніх можливостях і здібностях до подальшої успішної професійної діяльності.

4. Принции партнерства передбачає рівність сторін, добровільність прийняття зобов'язань, обов'язковість виконання домовленостей, паритетна комунікативна співпраця із застосуванням суб'єкт-суб'єктних стосунків.

5. Приниип ієрархічності розвитку $i$ зворотного зв'язку. За висловленням Альберта Ейнштейна, найзначущіші проблеми не можуть бути розв'язані на тому ж рівні мислення, на якому ми перебували, коли їх продукували. Повсякденно ми здійснюємо вибір, на підставі якого уживаємо певних заходів, реагуємо на інформацію, дії інших

Важливими є функції коучингу, які різняться залежно від виду професійної діяльності, кваліфікації, цілей його учасників [5, 23]:

- розвиваюча (забезпечує розвиток соціальної компетентності кожного вчителя/викладача, сприяє їхньому професійному зростанню, соціальній успішності, опануванню новими соціальними ролями);

-мотивуюча (сприяє досягненню соціальних цілей кожним педагогом, активізації процесу пізнання і самопізнання, накопичення соціального досвіду, пізнання себе в соціально-професійній діяльності);

-методична (використовують у різних формах роботи, на будь-якому етапі діяльності: планування, адаптація, мотивація, навчання й розвиток, атестація та оцінювання);

-моніторингова (забезпечує педагога необхідною інформацією для прийняття соціально орієнтованих рішень);

-партнерська (здійснюється із врахуванням соціокультурних змін, трансформації ринку праці й забезпечує гармонізацію інтересів партнерів);

-niдтримуюча (забезпечує супровід учителя/викладача в розвитку його соціальної компетентності та всіх їі складових, зокрема й професійної);

-креативна (сприяє розвиткові творчого, соціально орієнтованого мислення, генерування нових ідей, прийняття креативних рішень); 
-сочіалізуюча (допомагає зрозуміти й гнучко сприймати соціальні зміни, опановувати нові соціальні ролі).

Колесниченко Ю. Л. зазначає, що в забезпеченні якості впровадження Концепції Нової української школи вчитель повинен володіти множинними ролями тренера:

- наставник;

- фасилітатор;

- лідер;

- консультант;

- менеджер.

Tехнологія проведення коучингу опирається на три важливі складові переконання, цінності й цілі.

Коучинг спрямований на реалізацію мети людини, вибір засобів i для iii досягнення послуговується рядом методів:

-метод конкретних ситуацій (передбачає оновлення власних знань, формування, розвиток, модернізацію компетентностей за допомогою аналізу та обговорення можливих розв'язків конкретних проблемних ситуацій);

-метод емоиійного стимулювання (втілюється у продукування позитивних почуттів і переживань до певного означеного виду діяльності, стійкий інтерес та мотивування до освітнього процесу);

-метод створення ситуації пізнавальної дискусї (продуктивний метод пожвавлення навчання, виявлення спектру думок членів групи, напрями досягнення цілі та спільного розв'язання проблеми, що викликає зацікавленість темою та бажання їі вирішити);

-«мозаӥка» (метод самостійного розподілу обов'язків у студентській групі для формування в них здатності незалежно, без сприяння викладача-коуча приймати обгрунтовані рішення та нести відповідальність);

-метод проектів (особистісно орієнтована взаємодія членів групи, поєднана зі значним обсягом самостійної роботи та самоконтролю, що сприяє розвиткові творчих і дослідницьких здібностей студентів у процесі виконання елементів наукового дослідження в спільно досягнутому продукті; створює умови для розвитку мотивації в освітній діяльності; стимулює прагнення зрозуміти установки і погляди один одного.

Педагогічний коучинг спирається на загальновідомі методи освіти дорослих (спостереження, опитування, бесіда, тестування, моделювання тощо), метатехнології (інтерактивні, практико-зорієнтовані, тренінгові, адаптивні, акмеологічні, компетентнісно-зорієнтовані, ігротехнології), також має власні стандартизовані та апробовані процедури, моделі $i$ технологї самоактуалізації (SMATR, GROW, самокоучинг).

Здійснений структурно-логічний аналіз і систематизація (Толочко, 2019) уможливили створення таблиці 1 «Професіограма коуча в післядипломній педагогічній освіті» 3 характеристикою особливостей професійної підготовки, концептуалізацією системних якостей, знань, умінь, здатностей, сформованості, готовності, відповідальності і відповідності в синергізмі становлення і розвитку. 


\section{Професіограма коуча}

\section{в післядипломній педагогічній освіті}

\begin{tabular}{|c|c|}
\hline $\begin{array}{l}\text { Дефініція } \\
\text { поняття «коуч» }\end{array}$ & $\begin{array}{l}\text { фахівець із креативної взаємної діяльності незалежних учасників освітньо- } \\
\text { наукового процесу, яка здійснюється у формі діалогу, для віднаходження й } \\
\text { реалізації можливостей здобувачів освіти та забезпечення власного } \\
\text { освітнього, професійного, соціального й особистісного розвитку }\end{array}$ \\
\hline системні якості & $\begin{array}{l}\text { шанобливе ставлення до особистого та професійного досвіду, } \\
\text { поліідентичності кожного, емпатія, толерантність, безпека життєдіяльності та } \\
\text { інших видів, підтримка, безоціночна позиція, стійкість до стресів, системне i } \\
\text { позитивне мислення, прагнення до саморозвитку }\end{array}$ \\
\hline знання & $\begin{array}{l}\text { педагогіки та навчального предмета/дисципліни, психології, андрагогіки; } \\
\text { етичних норм і стандартів коучингу }\end{array}$ \\
\hline уміння & $\begin{array}{l}\text { ставити запитання, що розкривають інформацію, та ефективно спілкуватися; } \\
\text { створювати сприятливе психолого-педагогічно-комфортне середовище; } \\
\text { розробляти та втілювати результативний план коучингу }\end{array}$ \\
\hline компетентності & $\begin{array}{l}\text { (професійно-коучингову, морально-етичну, комунікативну, управлінсько- } \\
\text { відповідальнісну, проектну, інформативно-комунікаційну, мотиваційно- } \\
\text { розвиваючу); }\end{array}$ \\
\hline здатність & $\begin{array}{l}\text { усвідомлювати та створювати природні й довірчі взаємини, проявляючи } \\
\text { відверту, гнучку й упевнену манеру поведінки; адекватно вести себе в } \\
\text { обставинах, що виникають у процесі коучингу }\end{array}$ \\
\hline сформованість & $\begin{array}{l}\text { розуміння коучингу, його відмінності від консультування, психотерапії та } \\
\text { інших методів фахової підтримки клієнтів та ефективне його застосування }\end{array}$ \\
\hline готовність & $\begin{array}{l}\text { створення спільно зі здобувачем освіти перспективи для неперервного } \\
\text { навчання протягом сесій коучингу, життєвих і робочих ситуацій із метою } \\
\text { продукування подальших дій для ефективних результатів коучингу, освітнє, } \\
\text { наукове, технокорелятивне підприємництво }\end{array}$ \\
\hline відповідальність & $\begin{array}{l}\text { викладача за використання ефективної спонукально-стимулюючої } \\
\text { комунікації; визначення автентичної культурідентифікації потенціалу } \\
\text { особистісних переваг здобувачів освіти і основних сфер для навчання й } \\
\text { зростання, вирішувати важливі питання та розвиватися (отримувати } \\
\text { зворотній зв'язок, установлювати переваги і швидкість навчання, } \\
\text { рефлексувати та навчатися на досвіді) }\end{array}$ \\
\hline відповідність & $\begin{array}{l}\text { запитам щодо розкриття професійного потенціалу особи для максимального } \\
\text { підвищення ефективності }\end{array}$ \\
\hline
\end{tabular}

Аналіз психолого-педагогічної літератури та власні дослідження дають можливість визначити професійну науково-методичну компетентність коуча як інтегральну характеристику, що включає креативну взаємну діяльність незалежних учасників освітнього (освітньо-наукового) процесу, яка здійснюється у формі діалогу, для віднаходження й реалізації можливостей здобувачів освіти та забезпечення власного освітнього, професійного, соціального й особистісного розвитку; є сукупністю розвинених компетентностей (професійно-коучингової, морально-етичної, комунікативної, проєктної, управлінсько-відповідальнісної, інформативно-комунікаційної, мотиваційно-розвиваючої); професійну сформованість розуміння коучингу, його відмінності від консультування, психотерапії та інших методів фахової підтримки клієнтів та ефективне його 
застосування; відповідальність педагога за спонукально-стимулюючої комунікації; культурідентифікації потенціалу особистісних переваг здобувачів освіти i основних сфер для навчання й зростання, вирішення важливих питань та розвиток (отримання зворотного зв'язку, установлення переваг i швидкості навчання, рефлексія та навчання на досвіді); відповідність запитам щодо розкриття професійного потенціалу особи для максимального підвищення ефективності.

Аналіз досліджень вчених та власні наукові пошуки щодо видів компетентності викладачів-коучів закладів освіти подано нами в таблиці 2 «Види компетентностей коуча».

\section{Таблиия 2}

\section{Види компетентностей коуча}

\begin{tabular}{|c|c|}
\hline $\begin{array}{l}\text { Види } \\
\text { компетентностей }\end{array}$ & Суть компетентностей \\
\hline $\begin{array}{l}\text { Нормативно- } \\
\text { етична }\end{array}$ & $\begin{array}{l}\text { • розуміння етичних норм і стандартів коучингу та } \\
\text { застосування їх у всіх ситуаціях, що виникають у процесі коучингу: } \\
- \text { розуміє Норми Поведінки Міжнародної Федерації } \\
\text { Коучингу (ICF) та застосовує їх у власній поведінці; } \\
\text { - розуміє та неухильно дотримується Етичних Норм } \\
\text { Міжнародної Федерації Коучингу (ICF); } \\
\text { - ясно розрізняє коучинг, консультування, психотерапію та } \\
\text { інші методи професійної допомоги клієнтам; } \\
\text { - за необхідності рекомендує звернутися до відповідного } \\
\text { фахівця, уміє визначити, коли це необхідно і які наявні ресурси }\end{array}$ \\
\hline $\begin{array}{l}\text { Організаційно- } \\
\text { управлінська }\end{array}$ & $\begin{array}{l}\text { • здатність зрозуміти потреби залежно від конкретних } \\
\text { взаємодій з клієнтами під час коучингу та дійти згоди } 3 \text { потенційним } \\
\text { або новим клієнтом щодо коучингового процесу та взаємин: } \\
\text { - розуміє та ефективно обговорює } 3 \text { клієнтом правила i } \\
\text { конкретні параметри взаємин у коучингу (наприклад, логістику, } \\
\text { оплату занять, розклад, підключення третіх осіб, якщо це доцільно і } \\
\text { прийнятно); } \\
\text { - досягає угоди про те, що прийнятно в цих відносинах, а } \\
\text { що ні, що пропонується, а що не пропонується, про зони } \\
\text { відповідальності коуча і клієнта; } \\
\text { - визначає, чи є відповідність між його / іiі методами } \\
\text { коучингу і потребами можливого клієнта, яка забезпечить } \\
\text { ефективність коучингу }\end{array}$ \\
\hline $\begin{array}{l}\text { Морально- } \\
\text { особистісна }\end{array}$ & $\begin{array}{c}\text { • уміння створити безпечне середовище та підтримку, що } \\
\text { забезпечує постійну взаємоповагу та довіру: } \\
-\quad \text { виявляє справжню турботу про благополуччя та майбутнє } \\
\text { клієнта; } \\
- \text { постійно демонструє власну цілісність, чесність та } \\
\text { щирість; } \\
-\quad \text { укладає ясні угоди та виконує обіцянки; } \\
\text { - демонструє повагу до сприйняття клієнта, його стилю } \\
\text { навчання і до особистості клієнта; } \\
\text { - забезпечує постійну підтримку і підтримує нові моделі } \\
\text { поведінки та дії, включаючи ті, що стосуються прийняття ризику та }\end{array}$ \\
\hline
\end{tabular}




\begin{tabular}{|c|c|}
\hline & $\begin{array}{l}\text { боязні невдачі; } \\
\quad-\quad \text { запитує дозволу клієнта на проведення коучингу в нових, } \\
\text { ще незвичних, «чутливих» для клієнта зонах }\end{array}$ \\
\hline $\begin{array}{l}\text { Емоційно- } \\
\text { інтелектуальна }\end{array}$ & $\begin{array}{l}\text { • здатність бути повністю усвідомленим та створювати } \\
\text { невимушені взаємини з клієнтом, демонструючи відкриту, гнучку та } \\
\text { впевнену манеру поведінки: } \\
- \text { усвідомлено взаємодіє і залишається гнучким у процесі } \\
\text { коучингу, «танцюючи» в моменті; } \\
\text { - знаходиться в контакті } 3 \text { власною інтуїцією та довіряє } \\
\text { внутрішньому знанню іншого - «слухає внутрішній голос»; } \\
\text { - відкритий до незнання та приймає ризики; } \\
\text { - бачить багато способів роботи } 3 \text { клієнтом і кожного } \\
\text { моменту обирає найбільш ефективний; } \\
\text { - ефективно використовує гумор, створюючи відчуття } \\
\text { легкості та енергії; } \\
\text { - упевнено змінює перспективи та експериментує з новими } \\
\text { можливостями у власних діях; } \\
\text { - демонструє впевненість у роботі із сильними емоціями, } \\
\text { здатний керувати собою, не дозволяючи емоціям клієнта домінувати } \\
\text { та заплутувати себе }\end{array}$ \\
\hline Етико-естетична & $\begin{array}{cl}\text { • } & \text { бажає бути еталоном для колег-педагогів: } \\
- & \text { проявляє відданість професії педагога; } \\
- & \text { переконаний у значущій ролі коучингу в освітньому } \\
\text { процесі; } & \\
- & \text { знайомить із традиціями закладу освіти; } \\
- & \text { готовий захищати справи колег; } \\
- & \text { життєрадісний, гнучкий, наполегливий; } \\
- & \text { терплячий, толерантний, неприскіпливий; } \\
- & \text { увічливий і дотримується конфіденційності }\end{array}$ \\
\hline $\begin{array}{l}\text { Професійно- } \\
\text { активна }\end{array}$ & $\begin{array}{l}\text { уміння повністю сконцентруватися на тому, що говорить і } \\
\text { про що замовчує клієнт, зрозуміти сутність сказаного в контексті } \\
\text { бажань клієнта і підтримати процес висловлювання клієнтом своїх } \\
\text { почуттів та думок: } \\
\text { - концентрує увагу на клієнті і його планах, а не на своїх } \\
\text { планах, складених для клієнта; } \\
\text { - чує, що турбує клієнта та викликає в ньог сумніви, які } \\
\text { його цілі і переконання про те, що можливо, а що ні; } \\
\text { - виявляє відмінність між словами, інтонацією і мовою тіла; } \\
\text { - узагальнює, перефразовує, повторює і віддзеркалює те, що } \\
\text { сказано клієнтом, щоб переконатися в чіткості і правильності } \\
\text { розуміння; } \\
\text { - підтримує і надихає, приймає, вивчає і сприяє посиленню } \\
\text { вираження клієнтом його почуттів, сприйняття, заклопотаності, } \\
\text { переконань, припущень; } \\
\text { - інтегрує і вибудовує процес, виходячи з ідей та пропозицій } \\
\text { клієнта; } \\
\text { - підсумовує або розуміє суть того, що говорить клієнт, і } \\
\text { допомагає йому досягти своєї мети, а не захоплюватися довгими } \\
\text { описами; } \\
\text { - дозволяє клієнтові «випустити пар» або «роз’яснити» } \\
\text { ситуацію, не засуджуючи, не стаючи на той чи інший бік, щоб }\end{array}$ \\
\hline
\end{tabular}




\begin{tabular}{|c|c|}
\hline & перейти до наступних кроків \\
\hline $\begin{array}{l}\text { Комунікативно- } \\
\text { творча }\end{array}$ & $\begin{array}{l}\text { вдатність ставити запитання, що розкривають інформацію, } \\
\text { необхідну для отримання клієнтом максимальної користі від } \\
\text { взаємодії з коучем, та сприяють коучинговим взаєминам: } \\
\text { - ставить запитання, що відображають активне слухання та } \\
\text { розуміння погляду клієнта; } \\
\text { - ставить запитання, які провокують відкриття, осяяння, що } \\
\text { створюють цілеспрямованість і активність; } \\
\text { - ставить відкриті запитання, які породжують велику } \\
\text { ясність, нові можливості або знання; } \\
\text { - ставить запитання, які просувають клієнта в бажаному } \\
\text { напрямі, а не провокують знаходити докази або озиратися }\end{array}$ \\
\hline $\begin{array}{l}\text { Мовно- } \\
\text { експресивна }\end{array}$ & $\begin{array}{l}\text { • здатність ефективно спілкуватися протягом сесій коучингу } \\
\text { і користуватися тією мовою, яка справляє найбільший позитивний } \\
\text { уплив на клієнта: } \\
- \text { ділячись чим-небудь і даючи зворотний зв’язок, } \\
\text { висловлюється ясно, чітко та прямо; } \\
- \text { чітко формулює та перефразовує, проводить рефреймінг, } \\
\text { щоб допомогти клієнту зрозуміти, розібратися в тому, чого він хоче, } \\
\text { або в тому, у чому він не впевнений, поглянувши } 3 \text { іншої } \\
\text { перспективи; } \\
-\quad \text { ясно викладає цілі коучингу, програму сесії, мету } \\
\text { використання технік, методів або вправ; } \\
-\quad \text { використовує відповідну і поважну щодо клієнта мову } \\
\text { (наприклад, уникає дискримінації за статтю, расою, не використовує } \\
\text { специфічних технічних термінів, жаргонізмів); } \\
-\quad \text { користується метафорами та аналогіями, щоб допомогти } \\
\text { проілюструвати важливу думку або створити словесну картину }\end{array}$ \\
\hline Саморозвивальна & $\begin{array}{l}\text { • здатність створити спільно з клієнтом можливості для } \\
\text { безперервного навчання протягом сесій коучингу, а також під час } \\
\text { життєвих і робочих ситуацій, щоб продукувати нові дії, які найбільш } \\
\text { ефективно приведуть до обумовлених результатів коучингу: } \\
- \text { організовує мозкові штурми і допомагає клієнту визначити } \\
\text { ті дії, які дозволять йому продемонструвати, відпрацювати і } \\
\text { поглибити нові знання; } \\
\text { - допомагає клієнтові сконцентруватися та систематично } \\
\text { вивчати найбільш істотні для досягнення обумовлених цілей } \\
\text { коучингу конкретні проблеми і можливості; } \\
\text { - залучає клієнта до дослідження альтернативних ідей та } \\
\text { рішень, оцінку варіантів і прийняття відповідних рішень; } \\
\text { - підтримує активні експерименти і самопізнання, де клієнт } \\
\text { відразу ж пробує те, що було предметом обговорення і вивчення під } \\
\text { час сесії, у своїй роботі та житті; } \\
\text { - відзначає успіхи і здатності клієнта, сприяючи іхньому } \\
\text { подальшому зростанню; } \\
-\quad \text { кидає виклик припущенням та точкам зору клієнта, } \\
\text { провокуючи появу нових ідей і знаходячи нові можливості для дій; } \\
-\quad \text { підтримує або висуває точки зору відповідно до } \\
\text { встановлених цілей клієнта і, не симпатизуючи жодній із них, } \\
\text { переконує клієнта розглянути ї; } \\
-\quad \text { допомагає клієнтові «Зробити Це Прямо Зараз», під час }\end{array}$ \\
\hline
\end{tabular}




\begin{tabular}{|c|c|}
\hline & $\begin{array}{l}\text { сесії коучингу, забезпечуючи негайну підтримку; } \\
-\quad \text { підтримує робочу напругу, «розтяжку», заохочує } \\
\text { постановку складних завдань, але в той же час підтримує } \\
\text { комфортний темп навчання }\end{array}$ \\
\hline $\begin{array}{l}\text { Цільово- } \\
\text { планувальна }\end{array}$ & $\begin{array}{l}\text { • здатність розробити та втілити ефективний план коучингу } \\
\text { з клієнтом: } \\
- \text { узагальнює зібрану інформацію та визначає } 3 \text { клієнтом } \\
\text { план коучингу і цілі розвитку, що зачіпають проблеми та головні } \\
\text { сфери, які потребують вивчення і розвитку; } \\
- \text { формує план, що передбачає отримання досяжних, } \\
\text { вимірних, конкретних результатів і містить терміни досягнення; } \\
\text { - уносить у план зміни, якщо це потрібно в процесі } \\
\text { коучингу і при зміні ситуації; } \\
\text { - допомагає клієнтові відшукати й отримати доступ до } \\
\text { інших ресурсів із метою навчання (наприклад, до книг, до інших } \\
\text { фахівців); } \\
- \text { визначає і прогнозує перші значущі для клієнта успіхи }\end{array}$ \\
\hline $\begin{array}{l}\text { Управлінсько- } \\
\text { діяльнісно- } \\
\text { коригувальна }\end{array}$ & 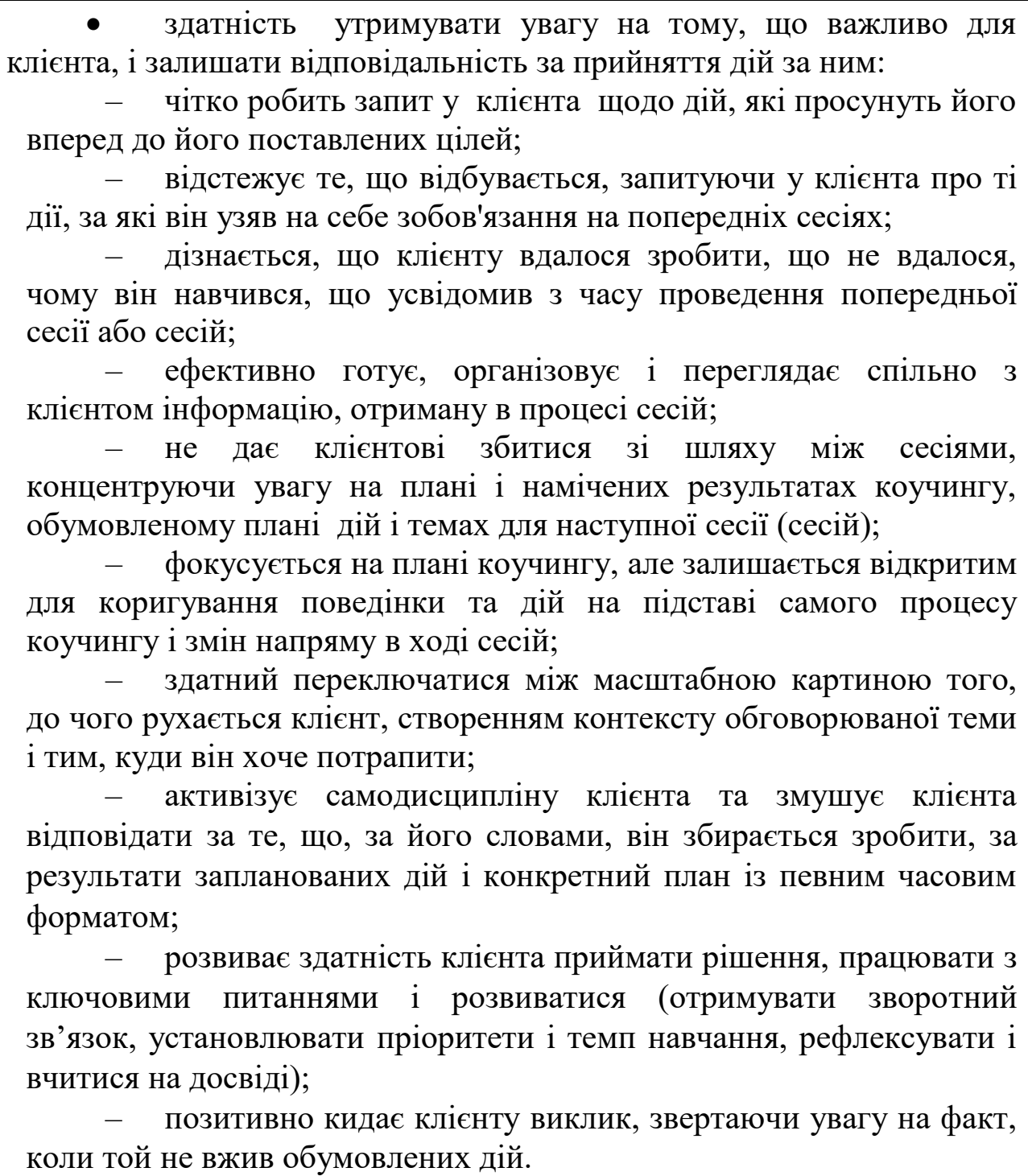 \\
\hline
\end{tabular}

\section{Очікувані результати та можливості реалізації коучингу в освіті}

Коучинг в освіті передбачає: 
- системний супровід студента, спрямований на ефективне досягнення важливих для нього цілей у конкретні терміни, у результаті чого в суб'єкта формується гнучкість і адаптивність до змін, здатність швидко й ефективно реагувати в критичних ситуаціях;

- партнерське комунікативне співробітництво, що допомагає добиватися значних результатів у різних сферах життєдіяльності;

- безперервний процес розвитку, удосконалення, розкриття потенціалу особистості для досягнення максимального результату;

- систему взаємодії з коучем, із самим собою, із навколишнім світом;

- технологію, що дозволяє переміститися зі сфери проблем у зону ефективного рішення;

- засіб сприяння, допомоги особистості в пошуку їі власних рішень у будьякій складній для неї ситуації;

- модель узаємодії суб'єктів, завдяки якій коуч-викладач підвищує рівень мотивації і відповідальності як у себе, так і у студентів: «навчається сам і вчить інших»;

- особливе підтримуюче ставлення до студента, згідно з яким він сам досягає своєї мети, вирішує проблеми, реалізуючи власні здібності і можливості;

- вид індивідуальної підтримки особистості, що ставить своїм завданням професійне й особистісне зростання, підвищення персональної ефективності;

- спосіб, що складається із таких кроків:

1) установлення партнерських взаємостосунків між викладачем i студентами;

2) спільне визначення завдань для досягнення конкретної мети;

3) дослідження поточної ситуації (проблеми);

4) визначення внутрішніх і зовнішніх перешкод на шляху до результату;

5) вироблення й аналіз можливостей для подолання труднощів у вирішенні проблеми;

6) вибір конкретного варіанту дій і складання плану дій;

7) домовленість про те, що конкретно повинно бути зроблено і в які терміни. Наступне коучинг-заняття завжди починається 3 огляду - що зроблено, що вдалося і що можна було зробити краще.

Висновки. Отже, педагогічний коучинг нині активно розробляється науковцями Національного педагогічного університету імені М.П. Драгоманова I. Голіяд, О. Тіщук, Т. Черновою (Інженерно-педагогічний факультет), ними розроблено авторський курс для майбутніх педагогів професійного навчання, отримано авторське право. Із 2016 року у Міжнародній школі коучингу та менторингу Master Coach Ukraine (Київ, Україна) для охочих засвоїти спеціалізацію педагог-коуч уведено курс «Педагогічний коучинг» із проходженням сертифікації.

Навчально-науковий Інститут магістерської підготовки та післядипломної освіти Університету «КРОК» здійснює підготовку за спеціалізацією «Коучинг» (http://fpo.krok.edu.ua/kursy/osobistisnii-rozvitok/kouching/k/), що уможливлює освоєння принципів, підходів i технологій педагогічного коучингу та значно підвищує його роль у професійному розвиткові особистості педагога. 


\section{Jimepamypa:}

1. Борова Т. А. Концепція освітнього коучингу. Педагогіка, психологія та медикобіологічні проблеми фізичного виховання і спорту. 2011. № 12. С. 11-12.

2. Варецька О. Коучинг як технологія розвитку соціальної компетентності вчителя початкової школи у системі післядипломної педагогічної освіти. Вісник Львівського університету. Серія педагогічна. 2016. Випуск 31. С. 349-361.

3. Гаврилюк О. Професійно-творча самореалізація вчителя в системі освіти дорослих. Педагогічні науки: теорія, історія, інновачійні технологї̈. 2016, № 8 (62). С. 116 - 126.

4. Колесниченко Ю. Л. Педагогічний коучинг як метод формування компетентнісного підходу, ключових компетентностей учасників освітнього процесу в умовах концепції Нової української школи. URL: http://komzoshpershotravnvk.odessaedu.net/en/article/pedagogichniikouching-yak-metod--formuvannya-komp.html

5. Петровська I. Р. Підвищення ефективності управлінської діяльності керівника за допомогою коучингу. URL: http://www.audytoriya.lviv.ua/

6. Поберезська Г. Г. Коучинг як педагогічна технологія студентоцентричного навчання у ВНЗ. Технологія і техніка друкарства. 2017. № 4(58) . С. 99-107.

7. Романова С. М. Коучинг як нова технологія в професійній освіті. URL: http://ecobio.nau.edu.ua/index.php/VisnikPP/article/viewFile/2145/2136

8. Сидоренко В.В. Педагогічний коучинг як інноваційна технологія науково-методичного супроводу професійно-особистісного розвитку вчителя в системі післядипломної освіти. URL: http://lib.iitta.gov.ua/106529/1/\%D1\%81\%D1\%82\%D0\%B0\%D1\%82\%D1\%82\%D1\%8F\%20\%D0\%9A $\% \mathrm{D} 0 \% 9 \mathrm{E} \% \mathrm{D} 0 \% \mathrm{~A} 3 \% \mathrm{D} 0 \% \mathrm{~A} 7 \% \mathrm{D} 0 \% 98 \% \mathrm{D} 0 \% 9 \mathrm{D} \% \mathrm{D} 0 \% 93 \% 20 \% \mathrm{D} 1 \% 81 \% \mathrm{D} 0 \% \mathrm{~B} 8 \% \mathrm{D} 0 \% \mathrm{~B} 4 \% \mathrm{D} 0 \% \mathrm{BE}$ $\% \mathrm{D} 1 \% 80 \% \mathrm{D} 0 \% \mathrm{~B} 5 \% \mathrm{D} 0 \% \mathrm{BD} \% \mathrm{D} 0 \% \mathrm{BA} \% \mathrm{D} 0 \% \mathrm{BE} . \mathrm{pdf}$

9. Сучасні моделі педагогічної професії в системі післядипломної освіти для сталого розвитку : навч.-метод. посібн. /упоряд. Толочко С. В. / Навчально-науковий інститут неперервної освіти НПУ імені М. П. Драгоманова. Київ; Ніжин, 2019. 312 с.

10. Толочко С. В. Теоретичні й методичні засади формування науково-методичної компетентності викладачів у системі післядипломної педагогічної освіти : дис...д-ра пед. наук : 13.00.04 / Національний педагогічний університет ім. М. П. Драгоманова. Київ, 2019. 574 с.

11. Толочко С. В. Концепція та методика формування науково-методичної компетентності викладачів у системі післядипломної педагогічної освіти : монографія. Київ : Вид-во НПУ імені М. П. Драгоманова, 2019. 376 с.

12. Толочко С. В. Управління формуванням системної методологічної компетентності в педагогів у сфері неперервної освіти впродовж життя. Управління системами післядипломної освіти для сталого розвитку: колективна монографія. Київ, 2019. С. 309-323.

13. Толочко С. В. Формування науково-методичної компетентності викладачів у системі післядипломної педагогічної освіти на засадах сталості : Стратегія післядипломної освіти для сталого розвитку : колективна монографія. Київ, 2020. С. 7-49.

14. Чернова I. Педагогічний коучинг в розвитку управлінської компетентності керівників професійно-технічних навчальних закладів. URL: http://lib.iitta.gov.ua/9233/

\section{References:}

1. Borova, T. A. (2011). Kontseptsiia osvitnoho kouchynhu. [The education coaching concept] Pedahohika, psykholohiia ta medyko-biolohichni problemy fizychnoho vykhovannia i sportu, 12, 1112 [in Ukrainian].

2. Varetska, O. (2016). Kouchynh yak tekhnolohiia rozvytku sotsialnoi kompetentnosti vchytelia pochatkovoi shkoly u systemi pisliadyplomnoi pedahohichnoi osvity [Coaching as a technology of developing the social competence of a primary school teacher in the system of postgraduate education]. Visnyk Lvivskoho universytetu. Seriia pedahohichna, 31, 349-361 [in Ukrainian].

3. Havryliuk, O. (2016). Profesiino-tvorcha samorealizatsiia vchytelia v systemi osvity doroslykh [The teacher's professional and creative self-realization in the system of adult education]. Pedahohichni nauky: teoriia, istoriia, innovatsiini tekhnolohii, 8 (62), 116 - 126 [in Ukrainian]. 
4. Kolesnychenko, Yu. L. Pedahohichnyi kouchynh yak metod formuvannia kompetentnisnoho pidkhodu, kliuchovykh kompetentnostei uchasnykiv osvitnoho protsesu v umovakh kontseptsii Novoi ukrainskoi shkoly [Pedagogical coaching as a method of forming a competency approach, key competencies of participants in the educational process in the concept of New Ukrainian school] Retrieved from http://komzoshpershotravnvk.odessaedu.net/en/article/pedagogichnii-kouching-yakmetod--formuvannya-komp.html [in Ukrainian].

5. Petrovska, I. R. Pidvyshchennia efektyvnosti upravlinskoi diialnosti kerivnyka za dopomohoiu kouchynhu [Improving the effectiveness of principle's managerial activity through coaching]. Retrieved from http://www.audytoriya.lviv.ua/ [in Ukrainian].

6. Poberezska, H. H. (2017). Kouchynh yak pedahohichna tekhnolohiia studentotsentrychnoho navchannia u VNZ [Coaching as a pedagogical technology of student-centered education in higher educational establishments]. Tekhnolohiia i tekhnika drukarstva, 4(58), 99-107 [in Ukrainian].

7. Romanova, S. M. Kouchynh yak nova tekhnolohiia v profesiinii osviti [Coaching as a new technology in vocational education. Retrieved from http://ecobio.nau.edu.ua/index.php/VisnikPP/ article/viewFile/2145/2136 [in Ukrainian].

8. Sydorenko, V.V. Pedahohichnyi kouchynh yak innovatsiina tekhnolohiia naukovo-metodychnoho suprovodu profesiino-osobystisnoho rozvytku vchytelia $\mathrm{v}$ systemi pisliadyplomnoi osvity [Pedagogical coaching as an innovative technology of scientific and methodological support of professional and personal development of a teacher in the system of postgraduate education] Retrieved from http://lib.iitta.gov.ua/106529/1/\%D1\%81\%D1\%82\%D0\%B0\%D1\%82\%D1\%82\%D1\%8F\%20\%D0\% 9A\%D0\%9E\%D0\%A3\%D0\%A7\%D0\%98\%D0\%9D\%D0\%93\%20\%D1\%81\%D0\%B8\%D0\%B4\%D 0\%BE\%D1\%80\%D0\%B5\%D0\%BD\%D0\%BA\%D0\%BE.pdf [in Ukrainian].

9. Tolochko, S. V. (2019). Suchasni modeli pedahohichnoi profesii v systemi pisliadyplomnoi osvity dlia staloho rozvytku [Modern models of the pedagogical profession in the system of postgraduate education for sustainable development] Navchalno-naukovyi instytut neperervnoi osvity NPU imeni M. P. Drahomanova. Kyiv; Nizhyn [in Ukrainian].

10. Tolochko, S. V. (2019). Teoretychni y metodychni zasady formuvannia naukovometodychnoi kompetentnosti vykladachiv u systemi pisliadyplomnoi pedahohichnoi osvity [Theoretical and methodical bases of formation of teachers' scientific and methodical competence in the system of postgraduate pedagogical education] Candidate's thesis. Kyiv: Natsionalnyi pedahohichnyi universytet im. M. P. Drahomanova [in Ukrainian].

11. Tolochko, S. V. (2019). Kontseptsiia ta metodyka formuvannia naukovo-metodychnoi kompetentnosti vykladachiv u systemi pisliadyplomnoi pedahohichnoi osvity [The concept and methods of formation of scientific and methodological competence of teachers in the system of postgraduate pedagogical education]. Kyiv: Vyd-vo NPU imeni M. P. Drahomanova [in Ukrainian].

12. Tolochko, S. V. (2019). Upravlinnia formuvanniam systemnoi metodolohichnoi kompetentnosti $\mathrm{v}$ pedahohiv u sferi neperervnoi osvity vprodovzh zhyttia [Management of formation of teachers' system methodological competence in the sphere of continuous education through life]. Upravlinnia systemamy pisliadyplomnoi osvity dlia staloho rozvytku: kolektyvna monohrafiia. Kyiv: Vyd-vo NPU imeni M. P. Drahomanova, (pp. 309-323). [in Ukrainian].

13. Tolochko, S. V. (2020). Formuvannia naukovo-metodychnoi kompetentnosti vykladachiv $\mathrm{u}$ systemi pisliadyplomnoi pedahohichnoi osvity na zasadakh stalosti [Formation of scientific and methodological competence of teachers in the system of postgraduate pedagogical education on the basis of sustainability] Stratehiia pisliadyplomnoi osvity dlia staloho rozvytku : kolektyvna monohrafiia. Kyiv: Vyd-vo NPU imeni M. P. Drahomanova. (pp. 7-49). [in Ukrainian].

14. Chernova, I. Pedahohichnyi kouchynh v rozvytku upravlinskoi kompetentnosti kerivnykiv profesiino-tekhnichnykh navchalnykh zakladiv [Edagogical coaching in the development of managerial competence of heads of vocational schools]. Retrieved from http://lib.iitta.gov.ua/9233/ [in Ukrainian]. 